\title{
Petroleum potential of sedimentary basins in Vietnam: long-term geoscientific co-operation with the Vietnam Petroleum Institute
}

\author{
Lars Henrik Nielsen and loannis Abatzis
}

The Vietnam Petroleum Institute (VPI) and the Geological Survey of Denmark and Greenland (GEUS) have carried out a programme of geoscientific research and institutional capacity building since 1995. It has included geoscientific projects focused on assessment of the hydrocarbon potential of selected sedimentary basins, technology transfer and inhouse training at VPI in Hanoi and at GEUS in Copenhagen. Co-operation is continuing within the framework of a new, long-term project that aims to strengthen research capacity in Vietnam within the fields of basin analysis and modelling.

\section{History of co-operation}

In 1993 CCOP-representatives (Co-ordinating Committee for Geoscience Programmes in East and Southeast Asia) visited GEUS to investigate the possibility of co-operation within research capacity development in the CCOP-countries. The Danish Energy Authority (DEA) subsequently approved a project proposal, and the first joint project between VPI and GEUS was initiated in 1995. The commencement of geoscientific studies showed an urgent need for interpretation tools at VPI, and modern geological and geophysical interpretation facilities were installed at VPI in 1996 with support from the Danish International Development Assistance (Danida). Following the successful completion of the first geoscientific project, DEA approved funding for a second phase. The projects were accompanied by a series of CCOP workshops held at VPI, and 'On-theJob-Training' (OJT) programmes at GEUS for VPI geoscientists (Nielsen et al. 2003).

The two first geoscientific projects were aimed at an analysis of the hydrocarbon potential of the Song Hong Basin (Fig. 1). Seismic interpretation, field work, stratigraphic evaluation, and assessment of results from the few exploration wells drilled in the basin were carried out (Dien et al. 1997, 1998, 1999; Andersen et al. 1998, 1999; Nielsen et al. 1999). Seismic facies analyses together with investigations of thermally immature potential source rocks at localities in the Song Hong Basin where inversion structures expose oil-prone Oligocene lacustrine mudstones and thin coals, led to the identification of areas for future hydrocarbon exploration (Petersen et al. 2001, in press).

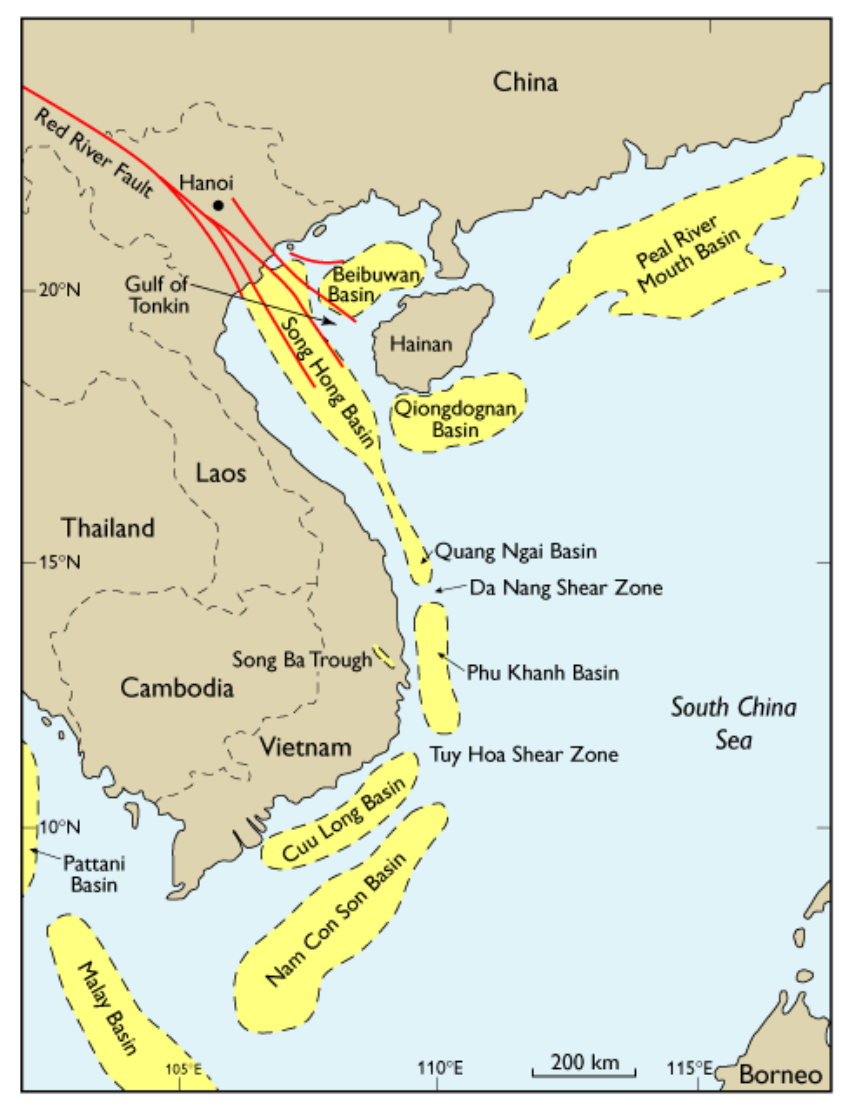

Fig. 1. Regional map showing the prospective Vietnamese Cenozoic offshore basins.

The implementation of these initial projects revealed a fundamental need for enhancement of the research skills of VPI geoscientists as part of an institutional development programme. An application for a long-term geoscientific research capacity building project was submitted to Danida's ENRECA project in the year 2000 .

\section{Basin analysis and assessment of hydro- carbon potential}

The ENRECA project was approved in August 2001. The main aims were to undertake an integrated analysis and modelling of sedimentary basins in Vietnam, to assess their hydrocarbon potential and to establish a geoscientific background 


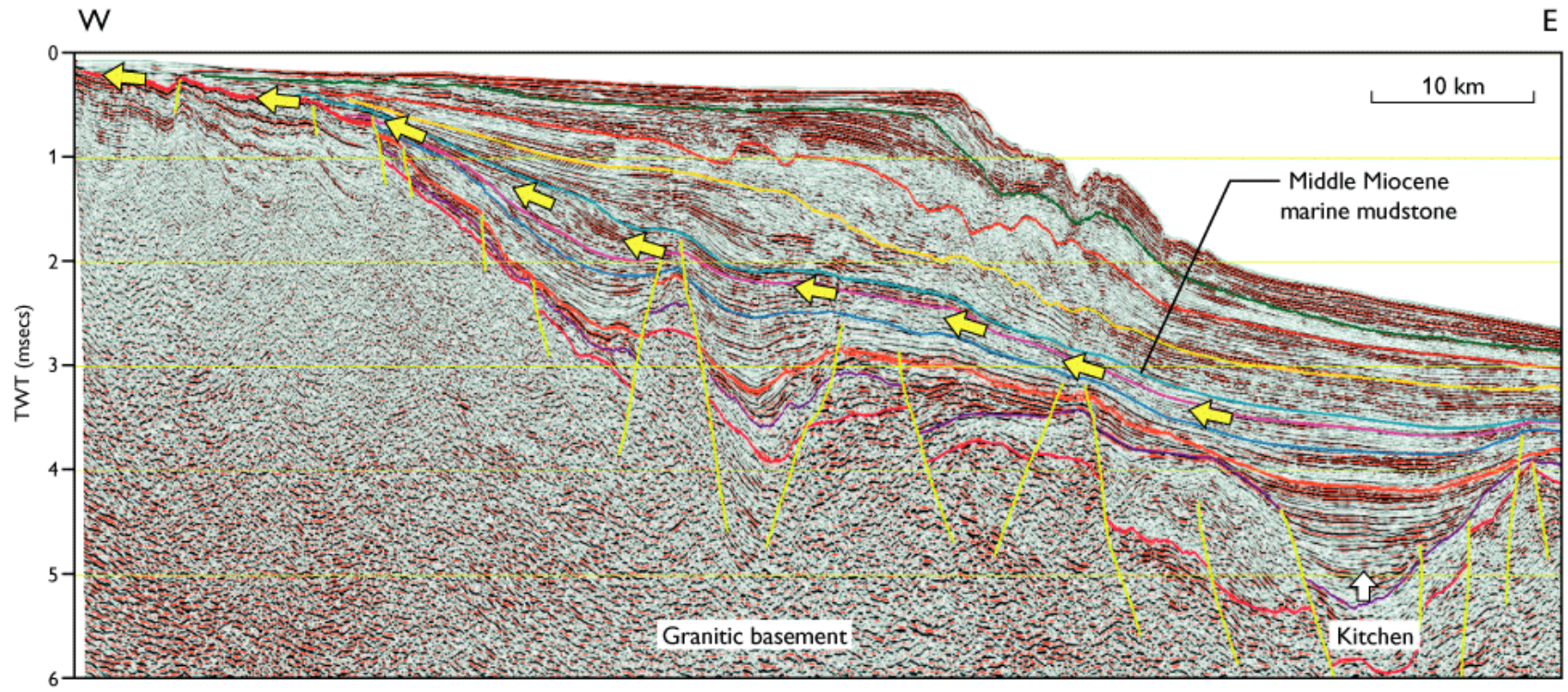

Fig. 2. Seismic profile of the Phu Khan Basin. The coastal oil seeps are located immediately west of the profile and indicate an updip migration path of hydrocarbons generated from a possible kitchen in the Phu Khanh Basin. For location, see Fig. 1.

on which decisions concerning exploration and exploitation of hydrocarbons could be based. The studies are carried out by geoscientists from VPI and GEUS, with support from scientists at the Hanoi University of Mining and Geology, Vietnam and the University of Copenhagen, Denmark. The first phase of the project, focusing on the Cenozoic Phu Khanh Basin offshore central Vietnam (Fig. 1), will last for three years; long-term co-operation can be extended in up to four phases.

One of the principal short-term objectives is to provide a research-driven assessment of the hydrocarbon potential of the basin. Activities initiated during the first phase of the project include seismic interpretation, field work, drilling of a $500 \mathrm{~m}$ deep core-well, geochemical and petrographic analyses, the initiation of five Vietnamese and four Danish M.Sc. studies, and several training courses.

\section{Seismic interpretation}

The Phu Khanh Basin is almost unexplored; it is covered only by an open seismic grid and no wells have yet been drilled. The Cenozoic basin-fill overlies strongly faulted older sedimentary rocks and granitic basement that crop out along the present-day coastline. The basement is cut by deep, listric, eastward-dipping faults formed during rifting, which probably began during the Palaeogene. The basin-fill consists of a syn-rift succession separated from the overlying post-rift succession by an unconformity that may be related to the opening of the South China Sea. On seismic profiles the syn-rift wedges are characterised by continuous reflectors interpreted to represent lacustrine sediments, i.e. potential source rocks, whereas transparent zones are interpreted to represent fluvial sands (Fig. 2).

The Middle Miocene to Recent post-rift succession can be divided into eight seismic sequences forming an eastwardthickening succession. The lower three sequences are thin, and their limited distribution is in part determined by structural uplift, whereas the more widely distributed overlying five sequences show distinct basinward prograding shelf-edge clinoforms. Analyses of the seismic facies and geometry of the sequences suggest a variety of sandy depositional environment, such as fluvial channels, shorefaces and basin floor fans that may all form potential reservoirs for hydrocarbons generated from syn-rift lacustrine source rocks. High amplitude reflectors over structural highs are interpreted as Miocene carbonate build-ups that can also form potential reservoirs.

\section{Oil seeps}

Oil seeps occurring at the basin margin have long been known from onshore coastal outcrops, but their nature has remained controversial. However, geochemical analyses of petroleum impregnation in cracks and fractures in weathered Cretaceous granites, tar mats on the beach, oil on vegetation, and mud with oil from shrimp-farm basins, have shown the presence of biodegraded petroleum, with biological markers pointing to a marly source rock with some terrestrial input (Bojesen-Koefoed et al. 2003, 2004). The oil contains 30norhopanes characteristic of carbonate-derived petroleum, as well as oleanane, a marker of contributions from angiosperm higher land plants. The presence of petroleum in narrow fissures in freshly cleaved granite testifies to the indigenous 
nature of the oil, and an origin from oil spills is therefore unlikely. Samples from shrimp basins show the presence of similar oil, although more altered by biodegradation. One sample collected from a tar mat on the beach shows characteristics similar to those of Cenozoic lacustrine oils found elsewhere in Vietnam, for instance in the Song Hong Basin. The close similarity of these oils suggests that pods of prolific lacustrine petroleum source rocks may be regionally distributed.

\section{Rift-lake successions and source rocks}

In order to investigate the formation and hydrocarbon potential of rift-lake systems associated with transtensional faulting, outcrop studies were carried out in the Song Ba Trough supplemented by studies of a continuous core from the 500 $m$ deep ENRECA-1 well. The Song Ba Trough was formed by transtensional faulting in the onshore continuation of the Tuy Hoa shear zone that marks the southern boundary of the Phu Khanh Basin (Fig. 1). The outcrops expose coarsegrained sandstones and conglomerates interbedded with lacustrine mudstones and scattered coal beds. The core-well encountered $480 \mathrm{~m}$ of sediments, beginning with thin fluvial sandstones overlying granite. The sandstones are overlain by lacustrine mudstones interbedded with thin sandstones, whereas fluvial sandstones dominate the upper part of the core. The lacustrine mudstones contain organic matter, commonly exceeding $5 \mathrm{wt} \%$, and many samples have a hydrogen index (HI) of more than $300 \mathrm{mg} \mathrm{HC} / \mathrm{g}$ TOC (total organic carbon), occasionally exceeding $700 \mathrm{mg} \mathrm{HC/g}$ TOC (Fig. 3). The organic matter is mainly composed of fluorescent amorphous organic matter, alginite and liptodetrinite, corresponding to type I kerogen, and may be an excellent source for oil. The results suggest that oil-prone mudstones were primarily formed in periods when the sedimentation rate was outpaced by formation of new accommodation space.

\section{Significance for future exploration activi- ties and research}

Interpretation of the seismic profiles suggests the presence of possible reservoirs and deep-seated kitchens in the Phu Khanh Basin. One possible kitchen is situated down-dip along a likely migration route to the oil seeps (Fig. 2). Thus, there is evidence that the common petroleum system found in south-east Asian basins, which rely on syn-rift lacustrine mudstones and coals, is also active in the Phu Khanh Basin. The investigated rift-lake succession in the onshore Song Ba Trough may thus be a valid analogue for older and deeply buried syn-rift sequences in the Phu Khanh Basin.

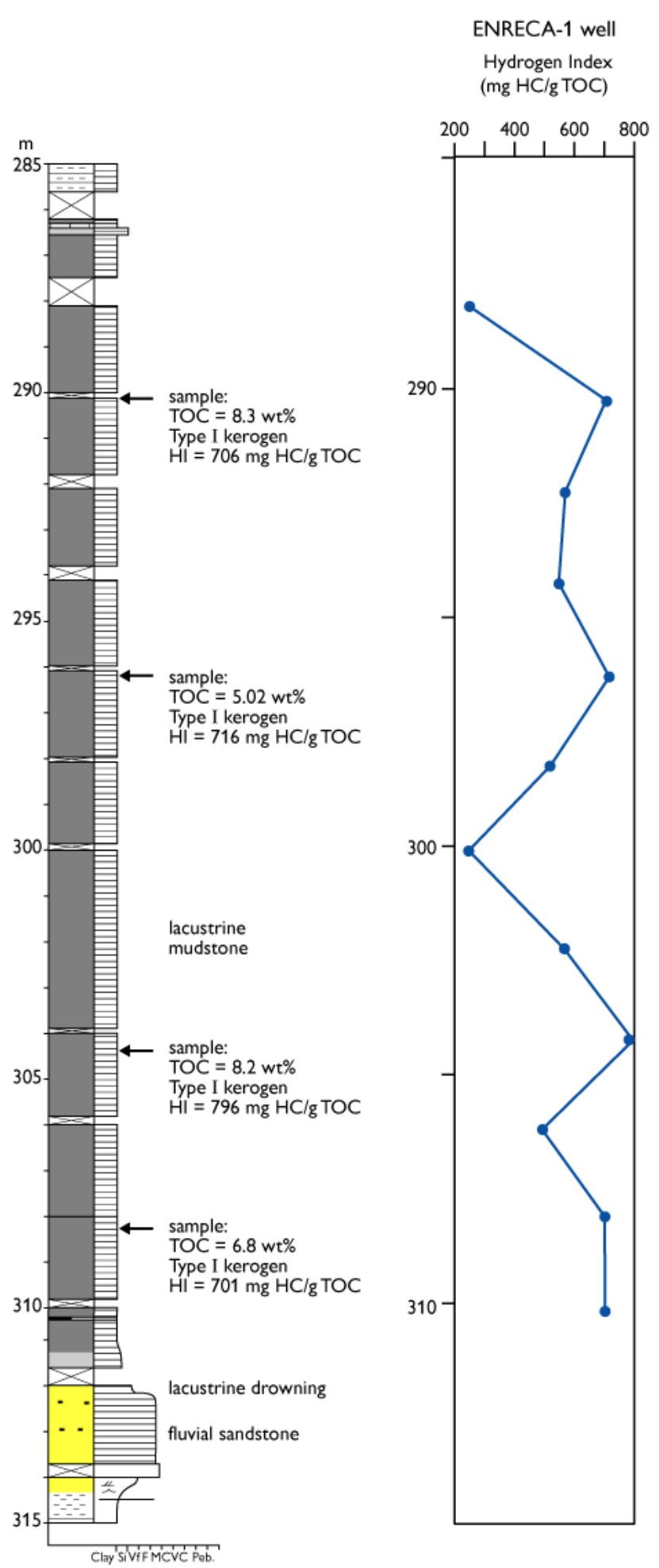

Fig. 3. Core $\log$ of a selected interval of the ENRECA-1 core-well, which penetrated a $500 \mathrm{~m}$ thick rift-succession of lacustrine mudstones. A significant amount of preserved organic matter indicates an excellent source rock for oil generation. The core-well is located in the Song Ba Trough, see Fig. 1. HC, hydrocarbon; HI, hydrogen index; TOC, total organic carbon. 


\section{Acknowledgements}

The Energy Research Programme of DEA, the Royal Danish Embassies in Hanoi and Bangkok, Danida's Fellowship Center and Danida are thanked for their financial support. VPI and PetroVietnam are acknowledged for their institutional support and permission to publish the results.

\section{References}

Andersen, C., Tiem, P.V., Mathiesen, A. \& Nielsen, L.H. 1998: Some new thermal maturity modelling results using the Yükler $1 \mathrm{D}$ software and seismic facies mapping in the northern part of the Song Hong Basin. In: Toan, T.N., Quy, N.H. \& Ngoc, N.V. (eds): Proceedings of Conference on Vietnam Petroleum Institute 20 years development and prospects. Hanoi, Vietnam, May 1998, 273-284.

Andersen, C., Mathiesen, A., Nielsen, L.H., Tiem, P.V. \& Dien, P.T. 1999: Petroleum systems in the northern part of the Song Hong Basin, Gulf of Tonkin - Vietnam. Proceedings from International Conference on tectonics, stratigraphy and petroleum and mineral systems of Palawan, Borneo and surrounding areas, Palawan Island, Philippines, 29 November - 3 December 1999 (CD-ROM).

Bojesen-Koefoed, J.A., Nytoft, H.P., Dau, N.T., Ha, N.T.B., Hien, L.V., Quy, N.H., Nielsen, L.H. \& Petersen, H.I. 2003: Geochemical characteristics of seep oils from Dam Thi Nai (Qui Nhon), central Vietnam implications for exploration in the offshore Phu Khanh Basin. 21st International Meeting on Organic Geochemistry, Krakov, Poland, 8-12 September, 2002. Abstracts 2, 193-194.

Bojesen-Koefoed, J.A., Nytoft, H.P., Dau, N.T., Ha, N.T.B., Hien, L.V., Quy, N.H., Nielsen, L.H. \& Petersen, H.I. 2004: Seep oils from Dam Thi Nai (Qui Nhon), central Vietnam; the ENRECA-project reports promising implications for the future exploration in the offshore Phu
Khanh Basin. In: Jarupongsakul, T. \& Saito, Y. (eds): 5th International conference on Asian Marine Geology. IGCP475 DeltaMap/ APN MegaDelta, Bangkok, Thailand, 13-18 January. Abstracts p. 25 only.

Dien, P.T., Nielsen, L.H., Andersen, C. \& Nhuan, D.V. 1997: Late Mesozoic to Cenozoic basin development along the north-west margin of the East Vietnam Sea. PetroVietnam Review 4, 5-10.

Dien, P.T., Nielsen, L.H., Andersen, A., Tiem, P.V. \& Nhuan, D.V. 1998 Late Mesozoic - Cenozoic events along the north-west margin of the East Vietnam Sea. In: Toan, T.N., Quy, N.H. \& Ngoc, N.V. (eds) Proceedings of Conference on Vietnam Petroleum Institute 20 years development and prospects. Hanoi, Vietnam, May 1998, 125-131.

Dien, P.T., Quy, N.H., Tiem, P.V., Tai, P.S., Andersen, C. \& Nielsen L.H. 1999: Basin analysis and petroleum system of the Song Hong Basin. In: Hiep, N. et al. (eds): Geology and petroleum in Vietnam, 44-67. Hanoi, Vietnam: Youth Publishing.

Nielsen, L.H., Mathiesen, A., Bidstrup, T., Vejbæk, O.V., Dien P.T. \& Tiem, P.V. 1999: Modelling of hydrocarbon generation in the Cenozoic Song Hong Basin, Vietnam; a highly prospective basin. Journal of Asian Earth Sciences 17, 269-294.

Nielsen, L.H., Abatzis, I., Petersen, H.I., Bojesen-Koefoed, J. \& Nytoft, H.P. 2003: Geo-scientific co-operation between Vietnam Petroleum Institute and Geological Survey of Denmark and Greenland, 1995-2002. Results, lessons learned, and views for the future. PetroVietnam Review 2, 32-48.

Petersen, H.I., Andersen, C., Anh, P.H., Bojesen-Koefoed, J.A., Nielsen, L.H, Nytoft, H.P., Rosenberg, P. \& Thanh, L. 2001: Petroleum potential of Oligocene lacustrine mudstones and coals at Dong Ho, Vietnam an outcrop analogue to terrestrial source rocks in the greater Song Hong Basin. Journal of Asian Earth Sciences 19, 135-154.

Petersen, H.I., Nytoft, H.P. \& Nielsen, L.H. in press: Characterisation of oil and potential source rocks in the northeastern Song Hong Basin, Vietnam: indications of a lacustrine-coal sourced petroleum system. Organic Geochemistry. 